\title{
- OPINIA PACJENTÓW NA TEMAT PRACY PIELĘGNIAREK
}

\section{PATIENTS' EVALUATION OF NURSING WORK}

\author{
Agnieszka Jurkiewicz ${ }^{1}$, Ewa Kobos ${ }^{2}$ \\ ${ }^{1}$ absolwentka studiów magisterskich kierunku pielęgniarstwo \\ Warszawski Uniwersytet Medyczny \\ ${ }^{2}$ Zakład Pielęgniarstwa Społecznego \\ Warszawski Uniwersytet Medyczny
}

DOI: https://doi.org/10.20883/pielpol.2017.64

\section{STRESZCZENIE}

Wstęp. Opieka pielęgniarska jest jednym z obszarów świadczeń zdrowotnych, który stanowi najbardziej bezpośredni kontakt z odbiorcą usług. Badanie opinii na temat pracy pielęgniarek daje możliwość oceny sprawowanej opieki pielęgniarskiej na przestrzeni czasu oraz porównanie wyników badań pomiędzy placówkami medycznymi.

Cel. Poznanie opinii pacjentów na temat pracy pielęgniarek.

Materiał i metody. Badaniami objęto 140 pacjentów hospitalizowanych. Narzędziem badawczym był autorski kwestionariusz ankiety. Dla potrzeb analiz aspekty pracy pielęgniarki poddane ocenie pacjentów sklasyfikowano w 7 obszarów. Wyniki badań przedstawiono za pomocą frakcji procentowych, statystyk opisowych oraz analizy wariancji ANOVA.

Wyniki. Dobrą opinię o pracy pielęgniarek wyraziło $69 \%$ pacjentów, $24 \%$ - dostateczną. Najwyższe średnie wartości w ocenie pracy pielęgniarki uzyskano $\mathrm{w}$ stwierdzeniach: pielęgniarki były sprawne w wykonywaniu swojej pracy, byłem traktowany z szacunkiem podczas kontaktu z pielęgniarką. Najniższe średnie wartości w ocenie pracy pielęgniarek uzyskano w stwierdzeniach: byłem informowany, która pielęgniarka się mną opiekuje, pielęgniarki przygotowywały mnie do samoopieki w domu. Zmienne socjodemograficzne nie różnicowały istotnie oceny pacjentów.

Wnioski.

1. Obszar pracy pielęgniarki, jakim jest informowanie i edukacja oraz przygotowanie pacjenta do samoopieki, powinny ulec poprawie.

2. Pielęgniarki w pracy zawodowej powinny przywiązywać większą wagę do wspierania pacjentów emocjonalnie.

SŁOWA KLUCZOWE: opieka pielęgniarska, opinie pacjentów.

\section{Wstęp}

Opieka pielęgniarska jest jednym z obszarów świadczeń zdrowotnych, który ma znaczący wpływ na poziom udzielanych usług medycznych [1]. W 2014 roku w Centralnym Rejestrze Pielęgniarek i Położnych były zarejestrowane 282522 pielęgniarki, ze średnią 48,43 roku, przez co stają się one "starą demograficznie grupą zawodową" [2]. Ze statystyk wynika, że wskaź-

\begin{abstract}
Introduction. Nursing care is one of the fields within healthcare provision that constitutes the most direct contact with the recipient of those services. Carrying out patients' opinion survey regarding nursing work gives opportunity for evaluation of nursing care over a period of time, and comparison of results between medical institutions.

Aim. Learning about patients' evaluation of nursing work.

Material and methods. Research included 140 patients treated in hospitals. The main research tool was author's own questionnaire. For the purpose of the analysis, nurses' work aspects evaluated by patients were classified into 7 domains. Research results were presented in a form of percentage fractions, descriptive statistics, and ANOVA variation analysis.

Results. $69 \%$ of patients expressed good opinion regarding nurses' work, and $24 \%$ - satisfactory. The highest average values evaluating nurses' work were achieved in response to the following statements: nurses were efficient in carrying out their work, I was treated with respect during contact with a nurse. On the other hand, the lowest average values evaluating nurses' work were given for these statements: I was informed about which nurse is taking care of me, nurses prepared me to self-care at home. Socio-demographic variables did not differentiate significantly patients' views.

Conclusions.

1. Nursing domain regarding informing and educating patients, and preparing patients to self-care should be improved.

2. Nurses should pay greater attention in supporting patients emotionally within the course of their employment.
\end{abstract}

KEYWORDS: nursing care, patients' opinions.

nik zatrudnionych pielęgniarek na 1000 mieszkańców w bezpośredniej opiece nad pacjentem dla Polski wynosi tylko 5,4. Obecna sytuacja demograficzna w Polsce to wzrost średniej wieku rodzących kobiet, wydłużanie średniej długości życia oraz ruchy migracyjne. Wydłużanie się przeciętnego trwania życia przy niskim poziomie liczby urodzeń prowadzi do starzenia się społeczeństwa. Coraz więcej osób starszych wyma- 
ga świadczeń opieki pielęgniarskiej. Pielęgniarek jest za mało, a trudna sytuacja ekonomiczna kraju prowadzi do dalszych redukcji [3].

W początkowym okresie powstawania pielęgniarstwa rola pielęgniarki była ograniczona do zapewnienia opiekuńczej pomocy chorym. Współcześnie pielęgniarstwo staje się znaczącą dyscypliną, a pielęgniarki stanowią istotne ogniwo zapewniania kompleksowej opieki nad pacjentem [4, 5]. Działania pielęgniarskie są ukierunkowane nie tylko na realizację funkcji opiekuńczej, ale również na edukację zdrowotną, promocję zdrowia, współudział w wysokospecjalistycznym leczeniu oraz działalność naukową [6, 7]. Realizując zadania zawodowe, pielęgniarka działa na rzecz człowieka i środowiska, własnego zawodu, nauki o pielęgnowaniu. Współczesna pielęgniarka powinna charakteryzować się profesjonalizmem, dążeniem do edukacji ustawicznej, otwartością na zachodzące zmiany, umiejętnością podejmowania szybkich decyzji, wyrażania własnej opinii i pracy w zespole oraz porozumiewania się z ludźmi [8, 9].

Odpowiedzialność zawodowa pielęgniarek polega na przestrzeganiu zasad etyki zawodowej oraz przepisów dotyczących wykonywania zawodu. Pielęgniarki ponoszą odpowiedzialność za realizację zadań na nieodpowiednim poziomie. Czyny te najczęściej obejmują nieprawidłowe wykonywanie obowiązków zawodowych, brak odpowiednich kwalifikacji do wykonywania zawodu oraz brak należytej staranności. Może to również dotyczyć kwestii wykraczania poza swoje kompetencje, naruszenia tajemnicy zawodowej, braku szacunku dla intymności i godności pacjenta, braku właściwego informowania pacjenta o jego prawach oraz niezawiadomienia odpowiednich organów o błędach medycznych popełnionych przez współpracowników [10]. Oprócz odpowiedzialności za swoje czyny pielęgniarka odpowiada za stan zdrowia pacjenta oraz przygotowanie chorego do przyjęcia odpowiedzialności za swoje zdrowie. Pielęgniarka, wywiązując się ze swoich obowiązków, nie odpowiada jedynie wobec prawa, ale również wobec własnego sumienia [11]. W zawodzie pielęgniarki ważne jest poczucie odpowiedzialności za dokładne wykonywanie swoich obowiązków na odpowiednio wysokim poziomie. Odpowiedzialność pielęgniarki za własny rozwój i pogłębianie wiedzy gwarantuje wysoki poziom usług medycznych [12, 13]. Niezależność pielęgniarek zwiększa odpowiedzialność za podejmowane decyzje. Pielęgniarka jest zobowiązana przyjąć zawodową oraz osobistą odpowiedzialność za swoją prace [7].

Opinia pacjentów jest obiektywnym wskaźnikiem pracy pielęgniarek. Chorzy najbardziej odczuwają brak wystarczającej liczby personelu medycznego. Na opinię ma wpływ przestrzeganie zasad etycznych w pracy pielęgniarki, przestrzeganie praw pacjenta oraz komunikowanie się pomiędzy pielęgniarką a pacjentem.
Celem pracy było poznanie opinii pacjentów na temat pracy pielęgniarek.

\section{Materiał i metody}

Badaniami objęto 140 pacjentów hospitalizowanych (po 14 pacjentów z 10 oddziałów), spełniających następujące kryteria: pacjenci $>30$ lat, pobyt na oddziale $\geqslant 5$ dni, stan pacjenta umożliwiający przeprowadzenie badania, wyrażenie zgody na udział w badaniu.

Materiał badawczy zebrano, wykorzystując autorski kwestionariusz ankiety zawierający metryczkę oraz 47 pytań skalowanych. Dla potrzeb analizy stwierdzenia dotyczące opinii pacjentów na temat pracy pielęgniarek pogrupowano w 7 obszarów (Tabela 1). Ankietowani udzielali odpowiedzi w skali od 1 do 5 , w zależności od stopnia, w jakim zgadzają się z danym stwierdzeniem (1 - zdecydowanie się nie zgadzam; 5 - zdecydowanie się zgadzam). Wyniki badań przedstawiono w tabelach liczności i tabelach statystyk opisowych. W celu ukazania różnic w opiniach pacjentów na temat pracy pielęgniarki w zależności od zmiennych socjodemograficznych i klinicznych zastosowano test analizy wariancji ANOVA.

Najliczniejszą grupe stanowili respondenci w przedziale wiekowym 60-69 lat (32\%). W wieku 30-39 lat było $19 \%$ pacjentów, 17\% - w przedziale wiekowym 40-49 lat, 15\% - w przedziale wiekowym 50-59 lat, a $17 \%$ - w wieku 70 lat i powyżej. Kobiety stanowiły $54 \%$ badanej grupy. W mieście mieszkało 83\% badanych, na wsi - $17 \%$ pacjentów. Wykształcenie średnie posiadato $48 \%$ ankietowanych, $26 \%$ - wykształcenie wyższe, $18 \%$ - zawodowe, $8 \%$ - podstawowe. Osoby w związku małżeńskim stanowiły $75 \%$ badanych, stanu wolnego $11 \%$, osoby owdowiałe $-9 \%$, rozwiedzione $-5 \%$. W trybie planowym przyjęto do oddziału $64 \%$ pacjentów, $36 \%$ - w trybie pilnym. W oddziałach zachowawczych było leczonych $50 \%$ pacjentów, tyle samo w oddziałach zabiegowych. Największy odsetek pacjentów (48\%) stanowiły osoby przebywające w oddziale 5 dni, po $16 \%$ - 6 dni i powyżej 9 dni, 11\% - przebywający 7 dni, 9\% - przebywający 8 dni.

\section{Wyniki}

W kategorii stwierdzeń dotyczących zaspokajania podstawowych potrzeb pacjenci najniżej ocenili pomoc pielęgniarek przy spożywaniu posiłków ( $\mathrm{M}=4,12)$. Ustosunkowując się do tego stwierdzenia, mniej niż $80 \%$ respondentów wyraziło zdanie: raczej tak lub zdecydowanie tak. W pozostałych stwierdzeniach pozytywnie oceniło pracę co najmniej $80 \%$ ankietowanych. Najlepiej w tej kategorii stwierdzeń oceniono pomoc pielęgniarki przy podaniu różnych przedmiotów $(\mathrm{M}=4,49)$ (Tabela 1). 
Tabela 1. Ocena pracy pielęgniarek w 7 kategoriach stwierdzeń - statystyki opisowe

Table 1. Evaluation of nursing care by 7 statements' categories - descriptive statistics

\begin{tabular}{c}
\hline $\begin{array}{c}\text { Kategorie poddane ocenie i stwierdzenia/Evaluated catego- } \\
\text { ries and statements }\end{array}$ \\
\hline Zaspokajanie podstawowych potrzeb/Meeting basic needs
\end{tabular}

\section{Zaspokajanie podstawowych potrzeb/Meeting basic needs}

Pielegniarki udzielały mi pomocy przy wstawaniu z łóżka/ chodzeniu, kiedy tego potrzebowałam/em/Nurses provided $\quad 4,31 \quad 1,04$ support with getting out of bed / walking when I needed it

Pielęgniarki pomagały mi przy utrzymaniu czystości, kiedy

tego potrzebowałam/em/Nurses helpped me maintain cleanli- 4,22 1,07 ness when I needed it

Pielęgniarki pomagały mi przy spożyciu posiłków, kiedy tego

potrzebowałam/em/Nurses helpped me consume meals when 4,12 1,18 I needed it

Pielęgniarki ułatwiały mi kontakt $\mathrm{z}$ rodziną/Nurses facilitated contact with my family

Pielęgniarki pomagały mi w zmianie niewygodnej pozycji,

kiedy tego potrzebowałam/em/Nurses helpped me change $\quad 4,25 \quad 1,15$ from uncomfortable position when I needed it

Pielęgniarki pomagały mi, gdy potrzebowałam/em jakiejś

rzeczy, np. podanie kubka, basenu/Nurses helpped me when / 4,49 0,92 needed something, e.g. passing mug, or bed pan

\section{Umiejętności pielęgniarek/Nurses' skills}

Pielęgniarki starannie wykonywały czynności takie jak: pobieranie krwi do badań, podłączanie kroplówki, podawanie leków/

Nurses diligently approached such activities as: taking bloods 4,46 0,76 for testing, inserting drips, administering medication

Pielęgniarki podczas wykonywania czynności pielęgniarskich

myły ręce i zakładały rękawiczki/During nursing activities, nurses washed their hands and put on gloves

Pielęgniarka posiadała zawsze wszystkie środki do wykonania

u mnie zaleconych czynności/zabiegów/Nurse always had

complete equipment needed to perform recommended proce- $2,76 \quad 1,50$ dures/treatments

Pielęgniarki były sprawne w wykonywaniu swojej pracy/Nurses were efficient while carrying out their duties

Pielęgniarki nie ze wszystkim dawały sobie radę/Nurses not $\quad 3,98 \quad 1,44$ always managed all tasks at hand *

Pielęgniarki wiedziały, co robić, nie czekały na polecenia

lekarzy/Nurses knew what to do, they didn't need to wait for $4,36 \quad 0,73$ doctor's orders

\section{Wsparcie emocjonalne/Emotional support}

Pielęgniarki miały czas, by usiąść i porozmawiać ze mną/Nurses had time to sit down and talk to me

Pielęgniarki wspierały mnie emocjonalnie, łagodziły lęk

i niepokój/Nurses supported me emotionally, eased anxiety $\quad 3,63 \quad 1,13$ and fear

Pielęgniarki były zawsze gotowe do pomocy/Nurses were always prepared to help

Pielęgniarki wysłuchiwały wszystkich moich wątpliwości/Nurses listened to all of my doubts

Pielęgniarki pytały mnie o moje potrzeby/Nurses asked me about my needs

Informowanie i edukacja/Information and education

Pielęgniarki wyjaśniały mi, co mają zamiar przy mnie zrobić, zanim to robiły/Nurses explained me what they are going to do 2,55 1,20 before they approached me

Pielęgniarki informowały mnie, jak mam się zachować, np.: podczas zabiegu, po zbiegu, jak przyjąć podany lek/Nurses advised me about how to behave for example during treat-
Pielęgniarki dostarczały mi informacji dotyczących opieki/

pielęgnacii/Nurses provided me all information relating to my $\quad 4,17 \quad 0,83$ care/nursing

Otrzymałam/em jasne informacje od pielęgniarki// received clear infromation from nurse

Pielęgniarki przygotowywały mnie do samoopieki w domu (np.: w jaki sposób się odżywiać, poruszać, wykonywać różne zabiegi)/Nurses prepared me to self-care at home (e.g. what to $2,50 \quad 1,27$ eat, how perform different procedures, and about mobility)

Pielęgniarki pomogły mi w planowaniu moich potrzeb po wypisie/Nurses helpped me to plan my needs after discharge $2,51 \quad 1,45$ Pielęgniarki wyjaśniały mi wszelkie problemy zdrowotne/Nurses explained me all health issues

Komunikacja między pielęgniarką a pacjentem/Komunication between patient and nurses

Pielęgniarka poświęcała wystarczająca ilość czasu na roz-

mowę ze mną/Nurse offered me appropriate amout of time to $2,82 \quad 1,33$ talk to me

Kiedy miałam/em ważne pytanie do pielęgniarki, otrzymywa-

łam/em na nie zrozumiałą odpowiedź/When I asked nurse an $\quad 4,43 \quad 0,66$ important question I received clear answer

Kiedy miałam/em lęki i obawy związane za swoim stanem zdrowia, pielęgniarka rozmawiała o tym ze mną/When I felt anxious and scared because of my health, nurse was willing to $4,11 \quad 1,02$ talk to me about it

Pielęgniarka zwracała się do mnie w sposób lekceważący*/ Nurses treated and addressed me with disrespect *

Pielęgniarka zachęcała mnie do wyrażania myśli i odczuć

związanych ze zdrowiem/Nurse encouraged me to express my 4,29 $\quad 0,87$ feelings and desires regarding my health

Czuję się komfortowo/swobodnie podczas rozmowy z pielę-

gniarką/l feel comfortable/casually during conversations with $4,56 \quad 0,67$ the nurse

Pielęgniarka umożliwiła mi kontakt z rodziną/Nurses facilitated contact with my family

Koordynacja opieki pielęgniarskiej/Coordination of nursing care

Pielęgniarka zapoznała mnie z topografią oddziału i zasadami

obowiązującymi w oddziale/Nurse showed me around the $\quad 2,76 \quad 1,28$ ward and explained the rules that apply at the ward

Na bieżąco byłam/em informowana/y, która pielęgniarka się mną opiekuje/l was regularly informed aabout which nurse $\quad 2,13 \quad 1,21$ carred for me

Pielęgniarki pracowały w sposób zorganizowany/Nurses worked in a structured manner

Pielęgniarki szybko reagowały na dzwonki, na wezwanie/Nur ses quickly responded to buzzers, calls

Pielęgniarki posiadały informacje na temat aktualnego stanu mojego zdrowia, podjętych działań leczniczych i pielęgnacyjnych/Nurses hold information about my current health, reccomended medical and nursing treatment

$\mathrm{Na}$ oddziale panowała dobra atmosfera/There was a plesant atmosphere at the ward

Pielęgniarki były przy mnie zawsze, kiedy tego potrzebowałam/em/Nurses were with me always when I need it

$4,44 \quad 0,61$

Okazywanie troski i życzliwości/Showing care and compasion

Pielęgniarki troszczyły się tylko o moją sferę fizyczną/Nurses cared only about my physical needs *

Pielęgniarki były życzliwe i uprzejme/Nurses were kind and courteous

Pielęgniarki okazywały troskę podczas podchodzenia do mnie/Nurses showed commitment when they approached me

Byłem traktowany z szacunkiem podczas kontaktu z pielęgniarką/l was treated with respect during contact with a nurse

Respektowano moje wartości/My values were respected $\quad 4,06 \quad 0,91$ 
Pielęgniarki respektowały moje prawa jako pacjenta/My patient's rights were respected

Pielęgniarki interesowały się mną jako osobą/Nurses showed interest in me as a person

$4,64 \quad 0,55$

Pielęgniarki wykazywały obojętność na zgłaszane przeze

mnie problemy*/Nurses showed indifferent attitude towards $\quad 4,56 \quad 0,83$ issues reported by me*

*odwrócenie skali: zdecydowanie nie - 5, raczej nie - 4, trudno powiedzieć -3 , raczej tak - 2 , zdecydowanie tak - 1/*reversed scale: definitely not -5 , rather not -4 , hard to say -3 , most likely -2 , definitely yes -1

M - średnia/mean, SD - odchylenie standardowe/standard deviation

Źródło: badania własne

Source: author's own materials

W kategorii stwierdzeń dotyczących oceny umiejętności pielęgniarek opinie respondentów były zróżnicowane. Najniżej oceniono posiadanie przez pielęgniarkę wszystkich środków do wykonania czynności/zabiegów $(\mathrm{M}=2,76)$. Na to pytanie około $75 \%$ ankietowanych odpowiedziało raczej tak lub zdecydowanie tak. Spośród umiejętności pielęgniarek pacjenci najwyżej ocenili sprawność pielęgniarek $w$ wykonywanych czynnościach $(M=4,66)$.

W stwierdzeniach z kategorii wsparcie emocjonalne najlepiej oceniono gotowość pielęgniarek do niesienia pomocy $(M=4,43)$ oraz wysłuchiwanie wszystkich wątpliwości pacjentów ( $M=4,17)$. Najniżej ankietowani ocenili zainteresowanie pielęgniarek potrzebami pacjentów $(\mathrm{M}=3,33)$.

W kategorii informowanie i prowadzenie edukacji najlepszą opinię pacjenci wyrazili na temat informowania, jak mają się zachować podczas czynności pielęgniarskich $(M=4,32)$ oraz dostarczania informacji dotyczących opieki/pielęgnacji $(M=4,17)$. Gorzej respondenci ocenili przygotowywanie ich przez pielęgniarki do samoopieki w domu $(M=2,50)$ oraz informowanie o tym, jakim czynnościom będą poddawani ( $\mathrm{M}=2,55)$. Tylko $20 \%$ pacjentów odpowiedziało, że dostali bądź raczej dostali informacje na ten temat.

$Z$ danych wynika, że w komunikacji między pielęgniarką a pacjentem najgorzej oceniony był czas poświęcony na rozmowę $z$ pacjentem $(M=2,82)$. Tylko $20 \%$ ankietowanych uważa, że pielęgniarka poświęciła im wystarczającą ilość czasu na rozmowę. Na pytanie odnośnie zwracania się do pacjenta w sposób lekceważący $(M=4,66)$ aż $75 \%$ respondentów odpowiedziało zdecydowanie nie.

W kategorii koordynacji opieki pielęgniarskiej najsłabiej została oceniona praca pielęgniarki obejmująca: zapoznanie $z$ topografią oddziału i zasadami w nim obowiązującymi ( $M=2,76)$ oraz informowanie, która pielęgniarka zajmuje się danym pacjentem $(M=2,13)$. Najwyżej zostało ocenione posiadanie przez pielęgniar- ki informacji na temat aktualnego stanu zdrowia pacjenta $(M=4,64)$.

W kategorii stwierdzeń wyrażających troskę i życzliwość okazywaną przez pielęgniarki najniżej pacjenci ocenili troskę pielęgniarek tylko o sferę fizyczną pacjentów ( $M=2,54)$. Aż $63 \%$ negatywnych ocen było na ten temat. Najwyżej w pracy pielęgniarki zostało ocenione traktowanie pacjentów z szacunkiem $(M=4,66)$ oraz podmiotowo $(M=4,64)$.

Porównując wyniki ogółem uzyskane w poszczególnych kategoriach stwierdzeń, wykazano istotne różnice $(p=0,020)$ w opinii pacjentów oceniających poszczególne obszary pracy pielęgniarki. Najwyższą średnią wartość w skali ogółem uzyskano w kategorii zaspokajanie podstawowych potrzeb $(M=4,27)$. Pacjenci wysoko ocenili również troskę i życzliwość pielęgniarek $(M=4,25)$. Najniższą średnią wartość $(M=3,25)$ uzyskano w kategorii informowanie i prowadzenie edukacji (Tabela 2).

Tabela 2. Ogólna ocena pacjentów w poszczególnych kategoriach statystyki opisowe

Table 2. Average patient's evaluation in each category - descriptive statistics

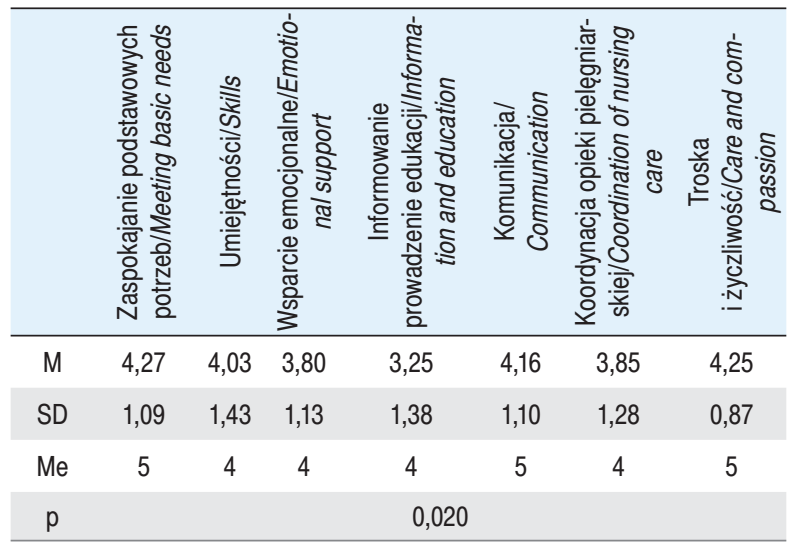

M - średnia/mean; SD - odchylenie standardowe/standard deviation; p - istotność statystyczna/statistical significance; $\mathrm{Me}$ - mediana/median

Źródło: badania własne

Source: author's own materials

W celu dokonania ogólnej oceny pracy pielęgniarek zsumowano wszystkie wartości uzyskane w skali każdego z pacjentów. W zależności od liczby uzyskanych punktów utworzono następujące kategorie opinii o pracy pielęgniarek: opinia bardzo dobra: 208-230 pkt, opinia dobra - 171-207 pkt, opinia dostateczna 116-170 pkt, opinia niedostateczna - poniżej 115 pkt. Dobrą opinię na temat pracy pielęgniarek wyraziło $69 \%$ pacjentów, $24 \%$ - opinię dostateczną, natomiast tylko $7 \%$ - opinię bardzo dobrą.

Z danych wynika, że wybrane zmienne socjodemograficzne nie wpływają istotnie na opinię pacjentów o pracy pielęgniarek $(p>0,05)$ (Tabela 3). Wykaza- 
no istotne różnice $\mathrm{w}$ opinii pomiędzy ankietowanymi z oddziałów zachowawczych i zabiegowych. Pacjenci z oddziałów zabiegowych znacznie lepiej ocenili pracę pielęgniarek ( $\mathrm{M}=4,01$ ) (Tabela 4). W przypadku rodzaju pobytu w szpitalu $(p=0,93)$ oraz liczby dni pobytu pacjentów w oddziale $(p=0,84)$ nie uzyskano istotnie statystycznego podziału grup.

Tabela 3. Ogólna ocena pacjentów a zmienne socjodemograficzne Table 3. Average patients' evaluation versus sociodemographic

\begin{tabular}{|c|c|c|c|c|c|c|}
\hline \multicolumn{3}{|c|}{ Pary zmiennych/Variable pairs } & \multirow{2}{*}{$\frac{M}{3,76}$} & \multirow{2}{*}{$\frac{S D}{0,06}$} & \multirow{3}{*}{$\frac{F}{2,51}$} & \multirow{3}{*}{$\frac{p}{0,11}$} \\
\hline \multirow{18}{*}{ 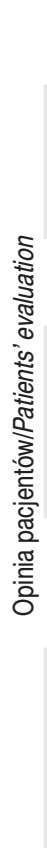 } & \multirow{2}{*}{ Płeć/Gender } & kobieta/female & & & & \\
\hline & & mężczyzna/male & 3,91 & 0,07 & & \\
\hline & \multirow{4}{*}{ Wiek/Age } & $<43 /$ below 43 & 3,91 & 0,10 & \multirow{4}{*}{0,82} & \multirow{4}{*}{0,49} \\
\hline & & $43-58$ & 3,86 & 0,07 & & \\
\hline & & $59-67$ & 3,82 & 0,10 & & \\
\hline & & > 67/67 or highier & 3,72 & 0,08 & & \\
\hline & \multirow{2}{*}{$\begin{array}{c}\text { Miejsce zamiesz- } \\
\text { kania/ } \\
\text { Place of residence }\end{array}$} & miasto/city & 3,84 & 0,05 & \multirow{2}{*}{0,62} & \multirow{2}{*}{0,43} \\
\hline & & wieś/village & 3,75 & 0,12 & & \\
\hline & \multirow{4}{*}{ Level of education } & podstawowe/primary & 3,91 & 0,16 & \multirow{4}{*}{0,22} & \multirow{4}{*}{0,88} \\
\hline & & $\begin{array}{c}\text { zawodowe/occupa- } \\
\text { tional }\end{array}$ & 3,84 & 0,09 & & \\
\hline & & średnie/secondary & 3,79 & 0,07 & & \\
\hline & & wyższe/higher & 3,86 & 0,09 & & \\
\hline & Stan & $\begin{array}{l}\text { zamężna/żonaty/ } \\
\text { married }\end{array}$ & 3,86 & 0,55 & \multirow[b]{2}{*}{0,49} & \multirow[b]{2}{*}{0,48} \\
\hline & Marital status & $\begin{array}{c}\text { niezamężna/nieżonaty/ } \\
\text { not married }\end{array}$ & 3,74 & 0,60 & & \\
\hline & \multirow{4}{*}{$\begin{array}{l}\text { Status zawodowy/ } \\
\text { Occupational status }\end{array}$} & pracuje/working & 3,83 & 0,06 & \multirow{4}{*}{1,74} & \multirow{4}{*}{0,16} \\
\hline & & nie pracuje/not wor- & 4,00 & 0,17 & & \\
\hline & & emeryt/pensioner & 3,73 & 0,07 & & \\
\hline & & rencista/annuitant & 4,17 & 0,31 & & \\
\hline
\end{tabular}

M - średnia/mean; SD - odchylenie standardowe/standard deviation; p - istotność statystyczna/statistical significance; F - analiza wariancji/ variance analysis

Źródło: badania własne

Source: author's own materials

Tabela 4. Ogólna ocena pacjentów a wybrane zmienne kliniczne Table 4. Average patients' evaluation versus clinical variables

\begin{tabular}{|c|c|c|c|c|c|c|}
\hline \multirow{4}{*}{ 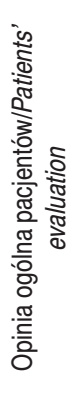 } & \multicolumn{2}{|c|}{ Pary zmiennych/Variable pairs } & M & SD & $\mathrm{F}$ & $p$ \\
\hline & $\begin{array}{c}\text { Pobyt w szpitalu/ } \\
\text { Hospital stay }\end{array}$ & $\begin{array}{c}\text { planowy/planned } \\
\text { nieplanowy/unplanned }\end{array}$ & $\begin{array}{l}3.83 \\
3.82\end{array}$ & $\begin{array}{l}0.06 \\
0.07\end{array}$ & 0.01 & 0.93 \\
\hline & $\begin{array}{l}\text { Rodzaj oddziału/ } \\
\text { Type of ward }\end{array}$ & $\begin{array}{l}\text { oddział zachowawczy/ } \\
\text { conservative ward } \\
\text { oddział zabiegowy/ } \\
\text { treatment ward }\end{array}$ & 3.64 & 0.06 & 19.01 & 0.00 \\
\hline & $\begin{array}{l}\text { Liczba dni po- } \\
\text { bytu na oddziale/ } \\
\text { Number of days } \\
\text { spent at the ward }\end{array}$ & $>5$ dni/>5 days & 3.84 & 0.07 & 0.04 & 0.84 \\
\hline
\end{tabular}

M - średnia/mean; SD - odchylenie standardowe/standard deviation; p-istotność statystyczna/statistical significance; F - analiza wariancji/ variance analysis

Źródło: badania własne

Source: author's own materials

\section{Dyskusja}

Badanie opinii na temat pracy pielęgniarek daje możliwość oceny sprawowanej opieki pielęgniarskiej na przestrzeni czasu oraz porównanie wyników badań pomiędzy placówkami medycznymi. Różnice między oczekiwaniami biorców usług a rzeczywistością mogą wpływać na zmianę zachowań pielęgniarek i w konsekwencji na zmianę opinii i satysfakcję pacjenta [14]. Z przeprowadzonych badań własnych wynika, że tylko $7 \%$ pacjentów oceniło bardzo dobrze pracę pielęgniarek. W badaniu Wyrzykowskiej [14] odsetek ocen bardzo dobrych był znacznie wyższy i wynosił 53,1\%. Podobnie kształtowały się wyniki badań Lisowskiej i wsp. nad oceną pracy pielęgniarek w oddziale pooperacyjnym. Ocenę wzorową wyraziło 53,5\% respondentów [15].

Z definicji pielęgniarstwa nawiązującej do opiekuńczej roli pielęgniarki wynika, że pielęgniarka asystuje choremu w czynnościach, które mają na celu powrót do zdrowia, oraz w tych czynnościach, których nie jest w stanie wykonać sam przez chorobę [16]. W stwierdzeniu z kategorii zaspokajanie podstawowych potrzeb dotyczącym pomocy pielęgniarek przy wstawaniu z łóżka/chodzeniu ponad połowa respondentów była zdania, że pielęgniarki zdecydowanie pomagają pacjentom w tego typu czynnościach. Na zbliżonym poziomie uzyskano wyniki w badaniu Wyrzykowskiej [14], w którym większość ankietowanych zgodziła się, że pielęgniarki zawsze pomagały pacjentom w uruchomieniu, oraz w badaniu Wasilewskiego [17] dotyczącym oceny jakości usług świadczonych przez pielęgniarki oddziałów neurologii i neurochirurgii, z którego wynika, że ankietowani wysoko ocenili zapewnienie pomocy pacjentowi przy siadaniu, wstawaniu i chodzeniu. Pacjenci nie mają również zastrzeżeń do aspektu pracy pielęgniarki związanego z pomocą przy zmianie pozycji sprzyjającej wypoczynkowi [14]. Z badań własnych wynika, że $80 \%$ pacjentów zdecydowanie zgadza się z tym, że pielęgniarki pomagają w zmianie niewygodnej pozycji.

Z badań Sierpińskiej i Dzirby [18] oraz badań własnych wynika, że trzy czwarte badanych ocenia bardzo dobrze pomoc pielęgniarki przy utrzymaniu higieny ciała. Nieco niżej ten aspekt pracy pielęgniarki został oceniony w badaniu Lisowskiej i wsp. W czynnościach pielęgnacyjnych około $60 \%$ ankietowanych przyznało pielęgniarkom ocenę wzorową [15]. Tylko połowa badanych pacjentów zdecydowanie zgodziła się z tym, że pielęgniarki pomagają pacjentom w karmieniu. Bardzo dobrze ten aspekt pracy pielęgniarek oceniło 80\% pacjentów w badaniu Sierpińskiej i Dzirby [18]. Niskie wyniki w badaniach własnych w stwierdzeniu dotyczącym pomocy przy spożywaniu posiłków mogą być 
skutkiem tego, że w badaniu uczestniczyli również pacjenci niewymagający pomocy ze strony drugiej osoby przy czynności karmienia oraz pacjenci przebywający w oddziałach, w których karmieniem chorych zajmują się opiekunowie medyczni. Niskie oceny pacjenci argumentują również brakiem informacji o zleconej diecie, a także podawanie zimnych posiłków [18].

W kategorii umiejętności najniżej oceniono posiadanie przez pielęgniarki wszystkich środków potrzebnych do wykonywania u pacjentów zleconych czynności/zabiegów. Może być to wynikiem braku dostępnych środków medycznych w szpitalu lub tego, że pielęgniarki zapominają o tym, co powinny ze sobą zabrać. Znaczna grupa pacjentów uważała, że pielęgniarki nie ze wszystkim dawały sobie radę. Przyczyną tego może być niedostateczna liczba pielęgniarek lub brak personelu pomocniczego w oddziałach. Na fakt, iż pielęgniarki są zapracowane i mają do wykonania na dyżurze zbyt wiele innych czynności, aby poświęcać czas pacjentowi, zwracają uwagę w swoich badaniach Gaweł i wsp. [13].

Poznanie przeżyć i sposobu zachowania się pacjenta w czasie choroby może być kluczowym elementem w prowadzeniu właściwej pielęgnacji i leczeniu [16]. $\mathrm{Na}$ rolę wsparcia emocjonalnego w pracy pielęgniarki z pacjentem jako wyznacznika jakości opieki zwraca uwagę w swoich badaniach wielu autorów [19-22]. W badaniu Glińskiej i wsp. tylko jedna piąta respondentów oceniła, że może zawsze liczyć na pomoc pielęgniarki w zakresie rozwiązywania swoich problemów w różnych sferach życia [23]. W badaniach własnych połowa pacjentów wyraziła opinię, że pielęgniarki zdecydowanie są gotowe nieść pomoc, nieco mniej niż połowa zdecydowanie zgadza się z tym, że pielęgniarki wysłuchują wszystkich ich wątpliwości, natomiast jedna trzecia respondentów wyraziła opinię, że pielęgniarki nie interesują się potrzebami pacjentów. W badaniach Mohammed i Odetoli 56\% ankietowanych zdecydowanie zgodziło się ze stwierdzeniem dotyczącym wysłuchiwania uskarżeń pacjentów [24]. Dużo wyższą ocenę tego aspektu pracy pielęgniarek wykazały badania Grochans i wsp. [19] dotyczące wsparcia emocjonalnego jako wyznacznika jakości opieki pielęgniarskiej. Zainteresowanie pacjentem oraz pytanie o jego potrzeby potwierdza $94 \%$ ankietowanych. Niepokojące jest to, że jedna trzecia pacjentów w badaniach nie zgadza się z tym, że pielęgniarki wspierały ich emocjonalnie oraz łagodziły lęk i niepokój. Może być to wynikiem braku wystarczającej ilości czasu dla pacjenta. Aż jedna czwarta respondentów nie zgodziła się ze stwierdzeniem, że pielęgniarki miały czas usiąść i porozmawiać z pacjentem.

Zgodnie z Ustawą z dnia 6 listopada 2008 r. o prawach pacjenta i Rzecznika Praw Pacjenta biorcy usług mają prawo uzyskać od pielęgniarki informację na temat działań pielęgnacyjnych oraz zabiegów pielęgniarskich. Pacjent ma prawo decydować o czynnościach, które mają być przeprowadzone [25]. Z badań wielu autorów wynika, że w ocenie około $80 \%$ pacjentów personel pielęgniarski przekazuje im informacje dotyczące celowości wykonywanych badań i podejmowanych wobec nich czynności oraz sposobu zachowania się podczas zabiegów [14-19], czego nie potwierdzają wyniki badań własnych. Jedynie jedna czwarta pacjentów zdecydowanie zgadza się z tym, że pielęgniarki wyjaśniają, co mają zamiar zrobić, zanim przystąpią do wykonania danej czynności, a połowa, że są informowani, jak mają się zachować podczas zabiegu, czy też przyjąć dany lek. Wyżej ten aspekt informowania ocenili pacjenci w badaniu Mohammed i Odetoli [24] oraz Wasilewskiego [17].

Pielęgniarka, realizując funkcję wychowawczą, odpowiada za motywowanie pacjenta do zmian na rzecz własnego zdrowia oraz za naukę nowych umiejętności, aby pacjent był zdolny do samoopieki po wypisie ze szpitala [26]. W badaniu Glińskiej i wsp. [23] 50\% ankietowanych pacjentów potwierdza prowadzenie przez pielęgniarki edukacji na temat zdrowego stylu życia i umiejętności życia z chorobą. Wyniki badań własnych wskazują, że $80 \%$ pacjentów uważa, że pielęgniarki dostarczają informacji dotyczących pielęgnacji. Zastrzeżenie budzi jednak opinia pacjentów na temat stopnia jasności przekazywanych informacji. W badaniach własnych tylko 35\% respondentów wyraziło pozytywną opinię w kwestii przekazywania jasnych informacji oraz dostarczania wiedzy do samodzielnej opieki. Wyniki badań Zhao i Akkadechanunt [27] dotyczące postrzegania jakości opieki pielęgniarskiej wskazują dużo wyższą ocenę pracy pielęgniarek w tym aspekcie. W badaniu Grochans i wsp. [19] na pytanie dotyczące przekazania w zrozumiały sposób informacji o pielęgnowaniu $76 \%$ ankietowanych odpowiedziało twierdząco. Wyniki badań własnych wskazują, że przygotowanie pacjenta do samoopieki w domu zostało ocenione nisko, co również ma swoje potwierdzenie w wynikach badań Wyrzykowskiej [14].

Prawidłowa komunikacja między pielęgniarką a pacjentem jest niezbędna do oceny jego problemów zdrowotnych oraz utrzymania zdrowia psychicznego. Rozmowa z pacjentem pozwala na zdobycie jego zaufania i nawiązanie pozytywnej relacji [28]. W badaniu Zhao i Akkadechanunt [27] pacjenci wyrazili opinię, że ilość czasu przeznaczana dla pacjenta przez pielęgniarki jest zadowalająca. W badaniach własnych jedynie $20 \%$ ankietowanych oceniło, że pielęgniarki poświęcają wystarczającą ilość czasu na rozmowę z pacjentami. Nieco lepsze wyniki uzyskał w swoim badaniu Wasilewski [17]. Około $62 \%$ ankietowanych stwierdziło, że personel pie- 
lęgniarski rozmawiał w wolnych chwilach z pacjentami, lecznie poświęcałim wystarczającejilościczasu. Autorzy badań w tym obszarze zwracają uwagę, że prowadzone z pacjentami rozmowy są niejasne, mało dokładne i fragmentaryczne [23] oraz że pielęgniarki zbyt mało czasu poświęcają na rozmowę, ponieważ skupiają się na wykonywaniu czynności instrumentalnych [29].

Praca pielęgniarki to nieustanny kontakt z drugim człowiekiem. Celem opieki pielęgniarskiej nie jest tylko zaspokojenie somatycznych potrzeb pacjenta, ale przede wszystkim wzmocnienie stanu psychicznego pacjenta poprzez szanowanie godności osobistej i holistyczne podejście. W związku z tym praca pielęgniarki wymaga znajomości zasad etycznego postępowania [30]. Wyniki badań własnych wykazały, że zdecydowana większość pacjentów (93\%) nie zgadza się ze stwierdzeniem, że pielęgniarki zwracają się do nich w sposób lekceważący. Podobne wyniki uzyskali Mohammed i Odetola [24]. W badaniach własnych 80\% osób potwierdza, że pielęgniarka zachęcała je do wyrażania odczuć związanych z ich stanem zdrowia. W badaniach Wyrzykowskiej [14] aż 54,2\% respondentów nie zgadza się z tym stwierdzeniem.

W badaniu własnym oraz Gniadek i wsp. [31] tylko $35 \%$ badanych potwierdziło, że byli zapoznani z topografią szpitala i oprowadzeni po oddziale. Nieco wyższy odsetek badanych (50\%) potwierdził ten fakt w badaniach Grochans i wsp. [19]. Zapoznanie pacjenta z topografią oddziału i obowiązującymi zasadami jest ważną czynnością dla nowo przyjętego pacjenta. Chory, znając miejsce, w którym się znajduje, czuje się pewniej i bezpieczniej. Pielęgniarka, pokazując oddział, ma okazję nawiązać kontakt z nowym pacjentem.

W badaniach mniej więcej połowa pacjentów podaje, że pielęgniarki zdecydowanie szybko reagowały na wezwanie/dzwonki chorego. Równie dobrze ten aspekt opieki pielęgniarskiej został oceniony przez pacjentów w badaniach innych autorów [18, 19]. Dostępność personelu w badaniu Zhao i Akkadechanunt została oceniona przez pacjentów średnio na 4,29 punktu i była nieco niższa niż w badaniach własnych [27].

Postawa i zachowanie pielęgniarek w trakcie pobytu pacjenta na oddziale mają duży wpływ na samopoczucie chorego, a także na szybki powrót do zdrowia [16]. W badaniach własnych respondenci ocenili atmosferę panującą na oddziale średnio na 4,07 punktu i był to wynik nieco niższy niż w badaniu Zhao i Akkadechanunt [27]. W badaniu Wyrzykowskiej [14] ponad 78\% pacjentów spotkało się z życzliwością, wyrozumiałością i uprzejmością ze strony pielęgniarek. Potwierdzają to również wyniki badań własnych i dostępnych w literaturze przedmiotu [15, 17, 19, 24]. W badaniach różnych autorów i własnym wysoko ocenione zostało także oka- zywanie troski, szacunku przez pielęgniarki podczas pracy z pacjentem [19, 24].

Wyższy wiek pacjentów został opisany w badaniach jako czynnik związany z lepszym postrzeganiem opieki [32]. Sugeruje się, że starsi pacjenci są bardziej tolerancyjni, mniej wymagający, wykazują więcej szacunku wobec personelu, nie skarżą się łatwo i rzadziej zgłaszają swoje potrzeby. Jednakże wyniki własne nie potwierdzają tej zależności. Badania zrealizowane w niemieckich szpitalach dotyczące wpływu czynników indywidualnych i organizacyjnych na postrzeganie indywidualnej opieki nad pacjentami potwierdzają, że pacjenci z wyższym poziomem wykształcenia postrzegają opiekę jako bardziej zindywidualizowaną [33]. W przeglądzie systematycznym dotyczącym satysfakcji pacjenta z opieki pielęgniarskiej Johansson i wsp. [34] sugerują, że im wyższy poziom wykształcenia pacjentów, tym większe są ich oczekiwania co do opieki pielęgniarskiej, co do informacji, które są przekazywane. W badaniach własnych nie zidentyfikowano różnic pomiędzy płcią i opinią na temat pracy pielęgniarek, choć niektórzy autorzy twierdzą, że kobiety postrzegają swoją opiekę inaczej i są mniej zadowolone z opieki, którą otrzymują.

Jeśli chodzi o badanie zależności między długością pobytu pacjentów w oddziale a ich zadowoleniem z opieki, Koberich i wsp. [33] otrzymali odmienne wyniki niż uzyskane w niniejszej pracy. Zgodnie z hipotezą autorów pacjenci, którzy przebywają dłużej w oddziale, silniej wiążą się z pielęgniarkami, są w stanie komunikować im swoje życzenia, a pielęgniarki są w stanie lepiej wziąć pod uwagę ich potrzeby. W badaniach własnych pacjenci oddziałów zabiegowych lepiej niż pacjenci oddziałów zachowawczych ocenili pracę pielęgniarek, co może wynikać z różnej specyfiki pacjentów przebywających w tych oddziałach. W badaniu Wyrzykowskiej [14] nie wykazano istotnej różnicy pomiędzy oddziałami.

\section{Wnioski}

1. Obszar pracy pielęgniarki, jakim jest informowanie i edukacja oraz przygotowanie pacjenta do samoopieki, powinny ulec poprawie.

2. Pielęgniarki w pracy zawodowej powinny przywiązywać większą wagę do wspierania pacjentów emocjonalnie.

\section{Piśmiennictwo}

1. Kopała W, Lesińska-Sawicka M. Mój zawód, moja pasja. Mag Piel Położ. 2014; 7-8: 8-9.

2. Zabezpieczenie społeczeństwa polskiego w świadczenia pielęgniarek i położnych. Raport. Warszawa: Naczelna Izba Pielęgniarek i Położnych; 2015, http://www.nipip.pl/attachments/article/3368/ Raport_2015_NIPiP.pdf (data dostępu: 10.12.2015).

3. Rogala-Pawelczyk G. Demografia nie kłamie. Mag Piel Po†oż. 2015; 6: 3-5. 
4. Kózka M, Gabryś T, Brzyski P, Ogarek M, Cisek M, Przewoźniak L, Ksykiewicz-Dorota A, Gajda K, Brzostek T. Wybrane czynniki determinujące ocenę jakości opieki pielęgniarskiej w szpitalach pełniących stały dyżur. Wyniki projektu RN4CAST. Zdr Publ Zarz. 2012; 10(4): 278-288.

5. Wołowski T, Piątak W, Nowalińska M. Ocena jakości opieki pielęgniarek uzdrowiskowych przez kuracjuszy. Ann Acad Med Gedan. 2010; 40: 109-116.

6. Dalkowska A, Dalkowski P, Gaworska-Krzemińska A, Krzemiński M. Historyczno-prawne regulacje zawodu pielęgniarki. Probl Piel. 2007; 15 (2-3): 115-119.

7. Glińska J, Lewandowska M. Autonomiczność zawodu pielęgniarskiego w świadomości pielęgniarek z uwzględnieniem pełnionych funkcji zawodowych. Probl Piel. 2007; 15(4): 249-253.

8. Siwek M, Chmiel I, Dzierga K. Postrzeganie zawodu pielęgniarki przez społeczeństwo z województwa małopolskiego. Piel XXI w. 2012; 4: 73-78.

9. Grabska K, Stefańska K. Sylwetka zawodowa pielęgniarki w opinii pacjentów. Probl Piel. 2009; 17(1): 8-12.

10. Gotlib J, Maliszewska A. Próba oceny wiedzy pielęgniarek na temat zakresu odpowiedzialności zawodowej w świetle znowelizowanych przepisów prawnych - doniesienie wstępne. Zdr Publ. 2013; 123(1): 57-61.

11. Wrońska I. Filozoficzne i etyczno-deontologiczne podstawy pracy pielęgniarki. W: Zahradniczek K (red.). Pielęgniarstwo. Warszawa: PZWL; 2004. 73-83.

12. Burhans LM, Alligood MR. Quality nursing care in the words of nurses. J Adv Nurs. 2010; 66(8): 1689-1697.

13. Gaweł G, Pater B, Potok H, Ogonowska D. Świadomość odpowiedzialności zawodowej wśród pielęgniarek. Probl Piel. 2010; 18(2): 105-110.

14. Wyrzykowska M. Ocena opieki pielęgniarskiej w opinii pacjentów. Piel Chir Angiol. 2007; 1: 3-10.

15. Lisowska B, Smolak A, Wielgus M. Ocena pracy personelu medycznego $w$ oddziale pooperacyjnym przez pacjentów po operacjach ortopedycznych. Anest Ratow. 2014; 8: 310-320.

16. Szutarska A, Andruszkiewicz A. Czynniki wyznaczające stan psychiczny i wpływające na ocenę opieki pielęgniarskiej. Piel Chir Angiol. 2010; 1: 1-5.

17. Wasilewski TP. Ocena jakości usług świadczonych przez pielęgniarki oddziałów neurologii i neurochirurgii. Zdrowie i Dobrostan. 2015; 2: 393-401.

18. Sierpińska L, Dzirba A. Poziom satysfakcji pacjenta z opieki pielęgniarskiej na oddziałach zabiegowych. Piel Chir Angiol. 2011; 1: 18-22.

19. Grochans E, Wieder-Huszla S, Jurczak A, Stanisławska M, Janic E, Szych Z. Wsparcie emocjonalne jako wyznacznik jakości opieki pielęgniarskiej. Probl Hig Epidemiol. 2009; 90(2): 236-239.

20. Kurowska K, Bystryk R. Rola wsparcia i przekonań dotyczących zdrowia w zmaganiu się z problemami wieku geriatrycznego. Geriatria. 2013; 7: 5-11.

21. Mróz J. Wsparcie od personelu medycznego a dynamika stanu emocjonalnego u pacjentów po zawale serca. Folia Cardiol Excerpta. 2013; 8(1): 9-13.

22. Wiśniewska L, Paczkowska B, Białobrzeska B. Zapotrzebowanie na wsparcie emocjonalne wśród pacjentów leczonych nerkozastępczo. Forum Nefrol. 2010; 3(1): 63-70.
23. Glińska J, Bednarska A, Brosowska B, Lewandowska M. Analiza poziomu jakości opieki pielęgniarskiej w opinii pielęgniarek i pacjentów. Piel Chir Angiol. 2012; 4: 151-160.

24. Mohammed MA, Odetola TD. Evaluation of patients' perception of nursing care in selected health institutions in Edo state, Nigeria. J Med Med Sci. 2014; 5(1): 12-19.

25. Ustawa $z$ dnia 6 listopada 2008 r. o prawach pacjenta i Rzeczniku Praw Pacjenta. Dz.U. z 2009 r. Nr 52, poz. 417 z późn. zm.

26. Ciechaniewicz W. Pielęgniarka - świadczeniodawca opieki pielęgniarskiej. W: Ślusarska B, Zarzycka D, Zahradniaczek K (red.). Podstawy pielęgniarstwa. Lublin: Czelej; 2009. 325-346.

27. Zhao SH, Akkadechanunt T. Patient's perceptions of quality nursing care in a Chinese hospital. Int J Nurs Midw. 2011; 3(9): 145-149.

28. Kler M. Komunikacja interpersonalna. Mag Piel Położ. 2015; 11: 40-41.

29. McCall E, Thomas L, Bond S. A study to determinate patient satisfaction with nursing care. Nurs Stand. 1996; 10: 34-38.

30. Pikor K, Tereszkiewicz J, Bar K. Życie i praca w ochronie zdrowia. Prz Urol. 2012; 2(72): 35-38.

31. Gniadek A, Malinowska-Lipień I, Zaniewska M, Cisek M. Wybrane aspekty satysfakcji pacjentów z pobytu w oddziałach chorób wewnętrznych szpitala w Krakowie. Piel XXI w. 2012; 4(41): 17-21.

32. Suhonen R, Land L, Valimaki M, Berg A, Idvall E, Kalafati M et al. Impact of patient characteristics on orthopaedic and trauma patients' perceptions of individualised nursing care. Int J Evidence Based Healthcare. 2010; 8(4): 259-267.

33. Koberich S, Feuchtinger E, Farin E. Factors infuencing hospitalized patients perception of individualized nursing care: a cross-sectional study. BMC Nursing. DOI 10.1186/ s12912-016-0137-7, https://www.ncbi.nlm.nih.gov/pmc/articles/PMC4774135/pdf (data dostępu: 10.12.2015).

34. Johansson P, Oleni M, Fridlund B. Patient satisfaction with nursing care in the context of health care: a literature study. Scand J Caring Sci. 2002; 16(4): 337-344.

Artykuł przyjęty do redakcji: 15.09 .2016

Artykuł przyjęty do publikacji: 20.03.2017

Źródło finansowania: Praca nie jest finansowana z żadnego źródła. Konflikt interesów: Autorzy deklarują brak konfliktu interesów.

\author{
Adres do korespondencji: \\ Ewa Kobos \\ ul. Erazma Ciołka 27 \\ 01-445 Warszawa \\ tel.: 228773597 \\ e-mail: kobewa@interia.pl \\ Zakład Pielęgniarstwa Społecznego \\ Warszawski Uniwersytet Medyczny
}

